\title{
Mental Space Elements of Vietnamese and English Perception Verbs
}

\author{
Phuong Nguyen Hoang \\ Department of Literature and Linguistics, University of Social Sciences and Humanities, Vietnam National University, Hochiminh City, \\ Vietnam
}

Email address:

ling.dr.phuong@gmail.com

\section{To cite this article:}

Phuong Nguyen Hoang. Mental Space Elements of Vietnamese and English Perception Verbs. International Journal of Language and Linguistics. Vol. 3, No. 1, 2015, pp. 27-32. doi: 10.11648/j.ijl1.20150301.15

\begin{abstract}
Perception is the procedure by which we interpret information about the environment that surrounds us. We can also say that perception is the gate to cognition. The perception process gives feedback about others and us. It is not always based on true picture of reality and we behave as though our perceptions are real. There are three key attributes to perception. The first is raw data. That is the information we experience. The second is the mental process, which is unseen but affected by things. The third is the product or that is our perception, sensing, or interpretation of our experience. In this article, we examine part of the second, the mental space elements of the perception verbs, Vietnamese and English in contrast. We inspected and collected 3,946 sentences with perception verbs as research data from two sets of English-Vietnamese, Vietnamese-English bilingual novels: The adventures of Sherlock Holmes and Love after war. We then used classify, statistic, descriptive, analysis, and contrastive methods to examine the research data. The results we have achieved for this research question are as followed. Basic mental space elements of the perception verbs include tangible and intangible factors. Tangible factors are preceptor/perceiver/experience/agent, perceived/stimulus, and perception organs. Intangible factors include spatial elements, ontological elements and information elements. Spatial elements are location, distance, path, direction, definition, layer, planning. Ontological elements are volition (volitional and non-volitional), way of cognition, sentient ability, culture, knowledge, ethnicity, geographic location, and way of thinking. Information elements are viewpoint and target.
\end{abstract}

Keywords: Perception, Cognitive, Mental Process, Factors, Tangible, Intangible

\section{Introduction}

Fillmore stated that frame semantics is "the system of concepts that has the relationship with each other in a way that to understand any concept of which, we have to understand the whole structure containing that concept" [3]. For instance, the concept of "hand" cannot be identified without the domain of "body"; the concept of "children" cannot be identified without the domain of "parents" either. And it is also impossible to understand the concept of "weekend" if we don't have a background knowledge of solar calendar (a week contains of 7 days) and of the cultural conventions (of working days and not working days). [3]

This background knowledge is called concept domain by Lakoff [6]. This is the semantic structure that plays the role of the background for the concept. It is also the knowledge structure providing background information from which we can understand and use the concepts in language. Lakoff also calls this human knowledge domain, which is organized with concept structures, idealized conceptual models.

According to Giles Fauconier [1, 16-21], any language pattern would create a mental space in the mind of the perceiver. This mental space is a simulation of the reality space in the mind of the language user. It is only valid in language, in the mind of the language user. It does not need to be highly precise as in natural sciences. For examples, the concepts of 'dragon', 'unicorn' only exist in the mental space. It is a large perspective body with multilayer. There are elements in each mental space. These spaces are created with the cognitive frames and the cognitive models, which is reflected by the language pattern. They are built depending on many factors such as schema building ability, background knowledge, analytical methods, synthesis, mapping, concept partition... of the perceiver. As with the concept of 'tree', we will recognize numerous affecting elements such as: a tree always has stems, leaves, branches; there are ground and space; is usually vertical; has a certain height, color; in a 
certain scene... The concept of 'tree' in the mind of each one is not totally identical.

Through the survey of the two sets of English-Vietnamese, Vietnamese-English bilingual novels: The adventures of Sherlock Holmesand Love after war, we collected 1950 units with Vietnamese perception verbs (nhìn, nghe, ngưi, nếm, sò and thấy) and 1996 units with English perception verbs (look, see, listen, hear, smell, taste, touch, feel). After having carefully processed, analyzed, and researched the data, we have the following mental space elements of Vietnamese and English perception verbs.

\section{Mental Space Elements of Vietnamese and English Perception Verbs}

The cognitive spaces that the perception verbs express in languages are extremely diverse and complex. This is because of the properties of the outside reality space reflected into our thinking and awareness. However, the basic mental space elements of the perception verbs include tangible and intangible elements.

\subsection{Tangible Elements}

The cognitive space is the reflection of the reality space.The tangible elements of the reality also exist in the cognitive space. These elements decide whether a cognitive action happens or not. They are the followings.

\subsubsection{Perceptor}

In a cognitive action, there is a perceptor / perceiver or the also called experiencer, or agent. Perceptor is the actor of the perception action.

Ex: (1) Con bé nhìn quanh. [III, 384]

She looked around. [IV, 343]

In the above example, 'She' is a single perceptor. This means that there is only one actor implementing the perception action. In the following example, there are multiperceptors.

Ex: (2) Vợ tôi, con tôi và người đàn bà vô danh nhìn tôi từ đáy nước. [III,31]

My wife,my son, and the nameless woman seem to be looking up at me from the bottom of the river. [IV, 14]

Next, in those two examples above, there is only one level of preceptor. We call this single-level perceptor. However, the objective world is an extremely complex and multi-level space. Therefore, a cognitive action can have multi-level perceptors. We can see it clearly in the example below in which 'Isa' is the first level perceptor of the action 'nhìn/look' and 'Tôi/I' is the second level perceptor of the cognitive action 'thấy/saw'.

Ex: (3) Tôi thấy Isa đang trố mắt nhìn ra phía tôi. [I, 86]

I saw Isa, pale, haggard, and unkempt, looking out at me. [II, 156]

Another interesting point is that the perceptor is sometimes clearly shown and sometimes invisible in the cognitive space. It can sometimes be outside the cognitive space and is implicit. We can see it in this example.

Ex: (4) Bình nhìn Mi. [III, 140]

Binh looked at Mi. [IV, 121]

The clearly shown perceptor in this cognitive space is 'Bình', the actor of the action 'nhìn'. However, to understand this cognitive space we can also imply that there is also another perceptor although this one is not shown in the utterance. Depending on the link with other cognitive space sequences, which makes appropriate scene, this implicit perceptor can be 'I', 'we', 'they'... Therefore, we can interpret the fully comprehension of example (4) as '(Tôi thấy) Bình nhìn Mi.' '(I saw) Binh looked at Mi.' with the shown first level perceptor is 'Bình' and the implicit second level perceptor is 'Tôi / I'. The following example is another interesting case.

Ex: (5) Chị nhìn trẻ hơn, thanh nhã hơn. [III, 53]

She looked younger and more elegant. [IV, 38]

In this example, there seem to be a clearly shown perceptor is 'chi/she'. However, this is not true. It is in fact the cognitive object and in this utterance, the presence of the perceptor is not shown. Therefore, the subject in the utterance and the perceptor are not always the same and sometimes they are two different ones.

\subsubsection{The Perceived}

Beside the perceptor, in a cognitive action, there is also the perceived entity or the perceived object, the perceived or stimulus.

Ex: (6) Sờ vào da thịt em xem có phải ma không? [III, 463]

Why don't you touch me and see if I am a ghost or not? [IV, 416]

Perceived entity is also as diverse as the perceptor. There are cases in which perceived entity is a single one or a set of entities. The perceived entity in (6) is a single one. The example below has a set of perceived entities.

Ex: (7) Tôi làm theo lời anh và thấy một chữ "E" lớn với một chữ "g" nhỏ, chữ "P" và một chữ "G" lớn với một chữ "t" nhỏ lồng vào nhau. [I, 7]

I did so, and saw a large "E" with a small "g", a "P", and a large " $G$ " with a small " $t$ " woven into the texture of the paper. [II, 14]

Perceived entity also has levels matching the levels of the perceptor. In example (8), 'bà/her' is the first level perceived entity of the action 'nhìn/look', which has the first level perceptor 'chồng bà/ her husband'. However, this perceptor itself turns into the second level perceived entity of the second level perceptor 'bà/ she' in the second level cognitive action 'thấy/ see'.

Ex: (8) Bà lạnh cả người khi thấy chồng bà đang nhìn xuống bà. [I, 89]

She was struck cold to see her husband looking down at her. [II, 161]

It is also necessary for us to note that in an utterance the perceived entity does not need to be present all the time. We can see this in the following examples.

Ex: (9) Lần này thì mọi người bước ra ngoài, ngước nhìn theo hướng tay tôi chỉ. [III, 456] 
This time everyone stepped outside, turning to look in the direction I was pointing. [IV, 410]

(10) Em chưa thấy bao giờ. [III, 572]

"I've never seen one", she exclaimed. [IV, 523]

\subsubsection{Perception Organs}

With each perception organ, every language has a certain number of perception verbs to describe the activities of these organs. Perception organs does not appear in utterances but are understood implicitly by default. However, their operational capacity is shown clearly and specifically in language.

Ex:(11) Điều đó thấyrõ trong đôi mắt nồng nhiệt của anh. [III,139]

You could see that clearly in his warm eyes, in his robust and resilient body. [IV,121]

(12) Nhưng tôi chẳng thấy gì cả. [I, 133]

But I saw nothing. [II, 240]

(13) Tôi lặng nghe Muôn hát, thấy giọt nước mắt lăn trên gò má của cô. [III, 533]

While she sang I listened in silence, watching the tears spill down her cheeks. [IV, 479]

(14) Cũng lạ, hễ mưa là ông ngửi thấymùi mốc ở cơ thể mình, mùi rữa nát ở đồ vật. [III, 586]

Whenever it rained he would smell that musty scent from his own body, the decaying odor of all his possessions, lying around him in the flat. [IV, 538]

(15)Mặn hay không chúng tôiđâu đã được nếm thử. [III, 552]

We haven't tasted it. [IV, 508]

(16) Mì rút tay khỏi áo Ngoan, sờ nhẹ lên môi Ngoan. [III, 221]

Mi withdrew her hands and raised them to touch Ngoan's lips softly. [IV, 206]

\subsection{Intangible Elements}

Tangible elements are finite. They have decisive role to the happening of the cognitive action. However, intangible elements of the cognitive space are even much more diverse and abundant. They dominate the way the cognitive action happens and the cognition result.

\subsubsection{Spatial Elements}

Reality world is a complex, objective space. Therefore, the cognition world is also a complex space to reflect the reality, objective world with the highest precision. There are the following elements.

\section{(i) Location}

This is the locationwhere the cognitive action happens. These locations are to locate the perceptor and the perceived entity. They are sometimes concrete but sometimes abstract and implicit in the relationship with the contexts.

a. Location of the perceptor

This is the location where the perceptor performs the cognitive action.

Ex: (17) Ở đó có thể thấy nhà em. [III, 392]

From there you can see my house. [IV, 349]

\section{b. Location of the perceived entity}

This is the location of the cognitive stimulus generated to lead the happening of the cognitive action.

Ex: (18) Nhưng nếu quả là từ ngoài bãi cỏ vọng vào thì sao em không nghe thấy? [I, 121]

And yet if it were on the lawn, I wonder that you did not hear it also. [II, 219]

\section{(ii) Distance}

For verbs of perception, the distance in the cognitive action is strongly reflected in the language structures.

Ex: (19)Muốn nhìn ở tầm gần không? [III,256]

Do you want to look at them close up? [IV,233]

(20) Cùng ngồi một bàn, còn có người đàn bà Việt Nam đứng tuổi, ăn mặc xềnh xoàng, đôi mắt đen lúc nào như cũng nhìn xa xăm. [III, 90]

Next to her was a simply clad Vietnamese woman of middle age, her dark eyes looking off as if into some distance. $[\mathrm{IV}, 76]$

\section{(iii) Path}

This is the way the stimulus of the sense goes from the source to the perceptor.

Ex: (21) Nhìn qua vai anh, tôi thấy một thiếu phụ, thân hình đẫy đà, đang đứng trên lề đường đối diện. [I, 70]

Looking over his shoulder, I saw that on the pavement opposite there stood a large woman. [II, 75]

\section{(iv) Direction}

This is the trend the cognitive action happens. This action can happen with the direction from the perceptor to the perceived entity.

Ex: (22) Con bé nhìn quanh. [III, 384]

She looked around. [IV, 343]

Alternatively, it can takes place in the opposite direction, from the perceived entity to the perceptor.

Ex: (23) Bà ngước lên, chợt thấy ông cũng đang loay hoay tìm cái gì đó. [III, 133]

She looked up and suddenly saw him, also hard at work searching for something.[IV, 114]

\section{(v) Definition}

A cognitive space contains a lot of information, so, it will be reflected with the definition or the volume of information. This is shown much in language, such as thấy rõ / clearly sees, thấy không rõ / sees not clearly, thấy hoi mờ vaguely sees, không thấy gì / sees nothing, thấy rất rõ tùng chi tiết / sees in detail ...

Ex: (24) Cánh cửa sổ mở và bà thấy rõ chồng mình đang hốt hoảng. [I, 89]

The window was open, and she distinctly saw his face, which she describes as being terribly agitated. [II, 162]

\section{(vi) Layer}

Cognitive space has the same features as the reality space. It always has a depth. This means it is a complex space with layers. We can easily verify this in language. The verb 'nhìn / look', for instance, has many language patterns such as nhin bên ngoài /look outside, nhìn bên trong / look inside, nhìn 
tùng mặt / look at each side, nhìn sâu hon / look closer...

Ex: (25) Bình nhìn vào trong xe. [III, 151]

He looked into the car. [IV, 131]

(26) Muốn nhìn ở tầm gần không? [III, 256]
Do you want to look at them close up? [IV, 233]

The cognitive space is sometimes expressed in the language with the structure of multilayer.

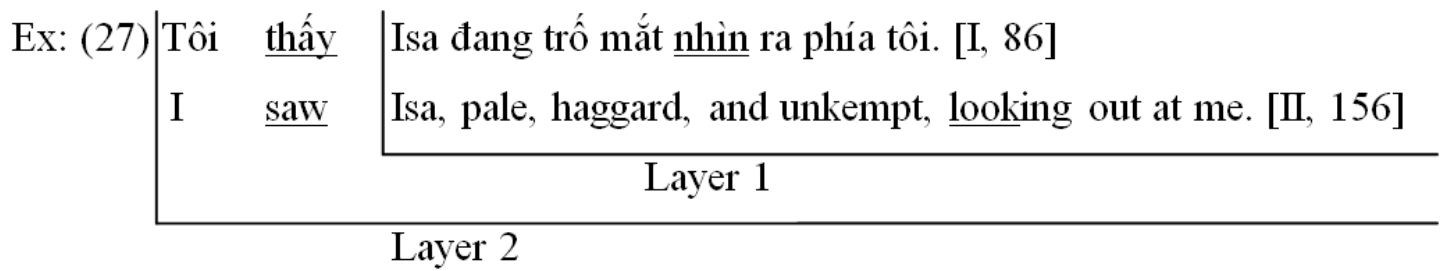

Figure 1. Layers of perception

\section{(vii) Planning}

Planning is the layout of the space. Because the cognitive space reflects the reality space, it is planned so that it can transfer the information to describe the world the best and the most precisely. In language, there are many ways to express the space planning. For example, with 'nhìn / look' we havenhin tổng thế / look overall, nhìn chi tiết / look in detail, nhin ngang / look from the side, nhin doc /look vertically, nhì tù duới lên / look from below, nhìn tù̀ trên xuống / look from above, nhìn toàn cảnh / look on the whole, nhìn toàn cuc / look thoroughly, nhì tổng quan / look in overview, nhin cu thể / look specifically...

Ex: (28) Biền quay ra ban công nhìn xuống bãi rác ở ven hồ. [III, 73]

Bien moved out onto the balcony to look down at the garbage dump along the edge of the pond. [IV, 57]

\subsubsection{Ontological Elements}

Human being, the subject of the language, is an extremely complex ontology. Ontological elements are in fact the nature and properties of the subject, which dominate language. They are truly the human attributes in language. When we examine languages, we have to consider all these attributes in order to understand languages fully. For the perception verbs, we have the following basic ontological elements.

\section{(i) Volition}

About this point, Leech [7, 28] described volitional perception: "I go out of my way, physically, to focus my attention on some object." Vendler [9] also stated that volitional perception verbs describe the actions in which the perceptor draws attention to the perceived entity. Therefore, according to those viewpoints, volitional perception has a metaphoric movement from the perceptor to the perceived entity and non-volitional perception is the opposite, from the perceived entity to the perceptor.

The volition of the perceptor is a very important factor, which has a decisive role to the cognitive mechanism of the perception verbs. It also helps differentiate the perception verbs into two groups: the volitional and the non-volitional ones. Within the viewpoint of cognitive linguistics, the nonvolitional group has a higher level of perception than the volitional one.

In example (29), the perceptor actively directs her attention to the cognitive object. Here the perceptor is the agent, which is volitional.

Ex: (29) Nàng cúi nhìn hắn lọt thỏm trong chiếc xe lăn tay. [III, 410]

Bending her head, she looked at him, sitting in his wheelchair. [IV, 376]

In example (30), the perceptor does not actively direct his attention to the cognitive object. Here the perceptor is only the experiencer, which is non-volitional.

Ex: (30) Ông ta sững lại khi thấy Trân và anh. [III, 192]

He stopped short upon seeing Tran standing together with the man. [IV, 182]

\section{(ii) Way of Cognition}

This is the way the cognitive action happens, the way the event takes place.

Ex: (31) Hắn cay đắng nhìn nàng. [III, 416]

He looked at her bitterly. [IV, 380]

(32) Hy vọng Roza sẽ tình cờ thấy qua một ô cửa tối tăm nào đó. [III, 497]

I hoped Roza would see me by chance from some dark slot of a window. [IV, 446]

\section{(iii) Sentient Ability}

This feature is for objects with perception ability, not for senseless objects.

Ex: (33) Căn phòng phía trước được trang bị như một phòng khách, nó dẫn vào một phòng ngủ nhỏ, nhìn ra một bến tàu. [I, 89]

The front room was plainly furnished as a sitting-room and led into a small bedroom, which looked out upon the back of one of the wharves. [II, 163]

Here 'phòng ngủ/bedroom' is not a perceptor. It is a senseless object. Therefore, in this language pattern, we cannot replace 'nhìn/look' with 'thấy/see' because 'phòng ngủ/bedroom' is not a perceptor with perception ability.

\section{(iv) Culture}

Culture is a factor affecting language cognition. For example, with the same language pattern: "Tôi thấy một con rồng. / I saw a dragon.”, however, if the listeners are different, an Asian and a European, the cognitive spaces built up in those two people's mind will be different. Each one will have different image and different properties. 


\section{(v) Knowledge}

Knowledge is also an element affecting language cognition. For example, with the same language pattern: "ngôi sao / star", however, if the listeners are different, one with good knowledge of physics and one without, the cognition ability of those two people will be very different. The one with good knowledge of physics will know that there is only one star in the Solar System, the Sun. The other may assume that there are ten stars.

\section{(vi) Ethnicity}

Ethnicity also affects language cognition. Asian, European, and African belong to different ethnicity. Therefore, in their minds, the concept of 'tall' for instance, will be very different. Their standard value of 'tall' is various.

\section{(vii) Geographic Location}

Geographic location affects language cognition deeply. It affects how the speaker would choose the language pattern. For example, in Vietnam, people from the Highlands say 'go down Saigon' or people from the Southwest say 'go up to Saigon'. This is totally because of the domination of geographical elements.

\section{(viii) Way of Thinking}

Human beings have thoughts. When we use language with consciousness, we need to think more. Thinking is a strong factor affecting languages. In contrastive study between English and Vietnamese, we find out some interesting points in the way of thinking. For example, in Vietnamese, we say 'một ngôi nhà đẹp' (a house beautiful). This means that we think from the whole to the properties. Meanwhile, in English, we say 'a beautiful house'. This is the way of thinking from the properties to the whole. As a result, Vietnamese likes deduction thinking while English likes induction thinking. This helps prove that thinking affects language cognition.

\subsubsection{Information Elements}

The function of the language is to contain and transfer information. Therefore, elements of information are very basic elements affecting language cognition. We will examine below two most basic elements that affect the cognitive space of the perception verbs.

\section{(i) Viewpoint}

In a cognitive action, viewpoint has a decisive role to the cognition result. In languages, viewpoint is a meaningful element for defining the meaning of a language pattern. Therefore, it is necessary to examine the viewpoint in the cognitive action of the perception verbs. We will look through these examples.

Ex: (34) Tôi nhìn anh ấy. [I, 147]

I look at him. [II, 143]

In this example, the viewpoint of this action is obviously from 'Tôi/ I' toward 'anh ấy/him'. However, in the below example, we have to think again about its viewpoint.

Ex: (35) Anh ấy nhìn đẹp trai. [I, 186]

He looks handsome. [II, 178]

Apparently, in this example, there is the phrase 'anh ấy nhìn / he looks' but in fact, 'anh ấy / he' doesn't have the action of 'nhìn / looks'. The viewpoint here must originate from an outside perceptor to 'anh ấy/he'. As a result, the perceptor is not all the time the subject of the sentence. Viewpoint identification has a very important role that helps semantics defining. For example:

Ex: (36) Anh ấy nhìn cũng được. [I, 239]

Without context, or without viewpoint, this sentence will lead to ambiguity.

$$
\begin{aligned}
& \text { Anh ây nhin cũng được (không đến nỗi xấu trai). } \\
& \text { He looks good. (not ugly) }
\end{aligned}
$$

Figure 2. Ambiguity of perception verbs

\section{(ii) Target}

According to the theory of information, any message generated has an information focus. Perception verbs have information focus, too. In the following example, the information focus is 'chiếc xe / the car' and 'sân / the ground' is only the background.

Ex: (37) Tôi thấy chiếc xe đậu trong sân. [I, 126]

(I saw the car packing in the ground.)

In linguistics, when we exchange the cognition focus in the same cognitive space to represent for a collective focus, we will have metonymy.

Ex: (38) Đó là chân sút chủ lực của đội bóng.

(That is the main foot of the team.)

In another case, if we exchange a cognition focus in this cognitive space to apply into another cognitive space, we will have metaphor.

Ex: (39) Ngày ngày mặt trời đi qua trên lăng, (The sun goes over the mausoleum everyday,)

Thấy một mặt trời trong lăng rất đỏ. (A really red sun can be seen in the mausoleum.)

\section{Conclusion}

The cognitive space of the perception verbs is a complex body containing various and diverse cognitive elements. They are tangible and intangible elements. They both appear inside the perceptor and outside the perceptor. They have not only the linguistic properties but also the properties of other sciences.

This article shows that cognitive space is a very 
appropriate theory that we can apply into the study of cognitive linguistics. It has been verified not only in linguistics but also in psychology, neurology, culture study, philosophy, ethnography, etc. The application of the cognitive space characteristics can help explain numerous linguistic problems extremely effectively such as metaphor, metonymy, conceptualization, the way language is formed in our mind and the way it is understood between speakers and listeners, the way we create and perceive language, etc.

Knowledge of these elements can be also very helpful for language teaching, learning, and translation. It helps learners, for instance, make utterances with the appropriate structure of preceptors, verbs and perceived entities. Then, learners can extend the sentences by adding complements of ways, position, direction, source, distance, etc. correctly and abundantly. Both learners and translator can better comprehend, reproduce, or translate if they grasp well how the viewpoint, the target, the perception ability...govern the semantics of the utterances.

\section{Corpus}

I.C. D. Arthur, Những cuộc phiêu lưu của Sherlock Holmes, Văn học, 2009.

II. C. D. Arthur, The adventures of Sherlock Holmes, The Project Gutenberg, 1999.

III. K. Wayne, H. A. Thái, Tình yêu sau chiến tranh, Hội Nhà văn, 2004.

IV. K. Wayne, H. A. Thái (edited), Love after war, Curbstone Press, 2003.

\section{References}

[1] G. Fauconnier, Mental Spaces, 2nd ed., Cambridge University Press, 1995.

[2] G. Fauconnier, Mappings in Thought and Language, Cambridge University Press, 1997.
[3] C. J. Fillmore, Scenes-and-Frames Semantics, in A. Zampolli, Linguistic Structures Processing, pp. 55-82, Amsterdam, 1977.

[4] C. J. Fillmore, Frame Semantics. Towards a descriptive framework for spatial deixis. Speech, place and action, New York, 1982.

[5] D. Geeraerts and H. Cuyckens, The Oxford Handbook of Cognitive Linguistics, Oxford University Press, 2007.

[6] G. Lakoff, Women, Fire and Dangerous Things - What categories reveal about the mind, University of Chicago Press, 1987.

[7] G. N. Leech, Meaning and the English Verb (3rd edition), Longman, 2004.

[8] A. Rojo and J. Valenzuela, Verbs of sensory perception: An English - Spanish comparison, John Benjamins, 2005.

[9] Z. Vendler, "Verbs and Times", The Philosophical Review, Vol. 66, No. 2,pp. 143-160, Cornell University, 1957.

[10] D. Geeraerts, Cognitive Linguistics: Basic Readings, Mouton de Gruyter, 2006.

[11] G. Kristiansen, Cognitive Linguistics: Current Apllications and Future Perspectives, Mouton de Gruyter, 2006.

[12] W. Croft and D. A. Cruse, Cognitive Linguistics, Cambridge University Press, 2004.

[13] V. Evans and M. Green, Cognitive Linguistics - An Introduction, Edinburgh University Press, 2006.

[14] M. Brdar, S. T. Gries and M. Z. Fuchs, Cognitive Linguistics Convergence and Expansion, John Benjamins Publishing Company, 2011.

[15] B. G. Bara, Cognitive Pragmatics - The Mental Processes of Communication, MIT Press, 2010.

[16] P. Robinson and N. C. Ellis, Handbook of Cognitive Linguistics and Second Language Acquisition, Routledge, 2008. 